\title{
A HUNGARIAN CLASSIC, BEAUTIFULLY TRANSLATED: ANTAL SZERB'S TRAVELER AND THE MOONLIGHT
}

\author{
ROBERT ZALLER \\ Drexel University \\ rzaller@msn.com
}

Modern Hungarian literature has never had a diligent and tireless proponent in the West such as Czeslaw Milosz was for that of Poland, but translation has slowly begun to make accessible one of the richest traditions of the twentieth century. Sándor Márai, Péter Nádas, György Sebestyén, Magda Szabó, and even the Nobel Prize-winning Imre Kertész are still on the margins of international literary history, but any proper account of it must take them as significant and even major figures in the modern novel. Their work, as an ensemble, constitutes a distinctive take on modernity as such, individual as each of them are in style, sensibility, and outlook.

To this number must be added the tragically short-lived Antal Szerb (19011945), who met his end in a forced labor camp at the end of World War II when he refused to be exempted from an execution order in solidarity with a friend. Szerb's masterpiece, Traveler and the Moonlight, is an acknowledged classic in Hungary, but the demeaning adjective "cult" often modifies it because of its intimations of the macabre. This is a fundamental misunderstanding. Szerb's novel is an exploration of the complex interweaving of two distinct but related phenomena: the socioeconomic decline of the Hungarian bourgeoisie in the aftermath of World War I, and the sense of characterological loosening and dissolution that accompanied it. Hungary had been the largest component of the Austro-Hungarian Empire, and, though its nationalist aspirations were intense, its mid-level elites, particularly in Budapest, experienced painfully the reduction of what had once been a major European capital to the status of chief city in a truncated East European country of modest size, no longer integrated within a greater Europe.

The book's major themes are sounded in its opening chapter. Mihály, its protagonist, is on a honeymoon in Venice with his new wife, Erzsi. One evening, pleading the need of a nightcap, he wanders off into the city's labyrinthine alleys, only returning at dawn to his distraught bride. The paragraph describing his experience not only suggests the deep structure of his character but that of his class and country:

What was this strange fascination, this feeling of bliss that caught up with him here among the alleys? Why did he feel as if he'd finally come home? Was it a 
dream a child dreams, a child in a fenced-in house who's threatened by vast, open spaces? The adolescent who'd rather live in a place so cramped that every inch had its own significance, where ten feet could mean the violation of a boundary? Where decades could be spent behind a rickety desk, where entire lives could pass sitting on one's behind in an armchair? If only he knew for certain ... (p. 5)

Mihály has avoided Italy on his travels because it symbolizes for him sexuality, breeding and thus adult responsibility. His trip down the alleys relieves him of this concern because their very narrowness suggests the constrained and therefore secure horizons of his childhood, which he hopes to maintain in maturity as someone tied to a desk - someone clerical or managerial, and therefore safely bourgeois. Mihály fears his marriage too, because it will force him to define himself in terms of another, an encounter he fears above all else. Only a prefabricated social role will ease his anxiety about himself. At the same time, though, he lacks the discipline of the bourgeois; he lives a desultory existence off his family's money, and the alleyways that lure him in Venice are an infantile regression, a quest for the inmost security of the womb.

As a symbol of the bourgeoisie, however - or at least the bourgeoisie in its decadence - Mihály also represents the fate of his country, whose elites find themselves with all too little "room" in the great world. For them, as for him, the past has acquired a retrospective glow that overlays a shabby present and an even more questionable future. There is no return to that past, of course, whether it be the memory of the Hungary that had been for a time the master of much of Eastern Europe or the proudly autonomous kingdom of the once-great Habsburg Empire. And because there is no return to it, it looms menacingly, both the ungraspable object of desire and the threatened engulfment of an abyssal nostalgia.

Mihály, in fact, complains of the fear of an abyss that had accompanied him throughout adolescence. These apparent panic attacks leave him paralyzed, but, although Mihály remains at all times lucid, Szerb suggests the political and metaphysical void beneath his seizures. He can find relief only with a brother and sister couple, Tamás and Éva, whose relations border on if they do not cross the barrier of incest, and who inhabit a fantasy world into which Mihály is admitted on the condition that he scrupulously play the parts assigned him. Mihály's innermost needs are met by this situation: he inhabits a world of uninhibited imagination with the perfect security of a slave. Éva, though imperious, does not threaten him, because her relationship with Tamás walls off any erotic temptation, while Tamás represents Mihály's idealized self: free, irresponsible, and aristocratically contemptuous of modernity. Mihály is ambiguously, or perhaps alternately in love with both brother and sister, which enables him to avoid entanglement with (or rejection by) either, this too being an infantile regression in which his actual peers become Oedipal parents. Mihály himself observes that Tamás and Éva seem androgynous to him, that is, interchangeable, and in that sense both equally 
attainable and equally remote. (Peter Hargitai, the book's translator, reveals in his afterword the secret revealed by Szerb's widow Klara to him, that the model for the two siblings was in fact a single person.)

Mihály's idyl breaks up when Éva's father betroths her to a repulsive bourgeois suitor. Tamás dies under circumstances later revealed to be a suicide, and Éva runs away. Now free to play the "brother", Mihály remains obsessed with finding Éva, while at the same time knowing their relationship can never be restored, let alone consummated. Abandoning Erzsi, he embarks on a peregrination through Italy that involves a near-fatal episode in a mountain village and a fruitless reunion with her in Rome. There is, too, the recollection of an enigmatic, perhaps supernatural experience of being led through a series of rooms in a seedy London flat where he senses but cannot reach Tamás, or at least his baleful spirit. Death, at any rate, seems closer to Mihály than life, and sinister presences pursue him, including a shady childhood friend and Erzsi's sleazy ex-husband. Another friend, who helps nurse him back from his accident, proves to be moribund himself, and when he looks up another acquaintance he finds in him someone even more death-obsessed than himself. These subordinate characters are all sketched with a vivid hand, as if death were a career; as the last-mentioned, Waldheim, says to Mihály:

I'm not talking about sickness and life-weary suicides, but those who, in the fulfillment of their lives, are drawn toward it, as toward the final ecstasy, the promise of rapture unto death ... Look, either you understand it or you don't. (167)

Mihály is certainly not fulfilled, either in love or career or even that which he seems to crave above all else, the pleasure of a solitude which is death's anteroom. He is variously tempted by lures as crude as bribery or as refined as ascetic saintliness, and it seems at times that he is being offered a "character", or at least a role, by everyone he meets. None fit, however, because no form of social existence, from the most abject to the most exalted, is to the point; Mihály is, to borrow Robert Musil's phrase, a man without qualities, that is without connection to the world around him. Such a person negates the world, not by rebelling against it but by passively refusing it, and, if his case becomes typical, that world will collapse.

The question is whether there is an alternative to such a collapse. Most of the novel takes place in Mussolini's Italy, whose fascism affects a spurious vitality based on social and economic regimentation. That fascism, in its more murderous Hitlerite incarnation, would take the Jewish Szerb's own life less than a decade later (on the very day, to bring irony full circle, when Auschwitz was liberated). Few could foresee the Holocaust in the mid-1930s, even if violent pogroms were already well underway. Inevitably, of course, we now read Traveler and 
the Moonlight through such a prism today, conscious as we are of the author's own tragic fate. Hargitai brings out the ominous premonitions of the Holocaust in his afterword, and of course we must read Traveler in that context today. But Szerb himself appears to have been conflicted about his heritage. Like Ervin, one of the principal characters in the text, he was a Jew converted to Catholicism, although unlike Ervin with no aspiration to sainthood. Perhaps Ervin represented for him a reconciliation of Judaism and Christianity in an ecumenical sense, an appreciation of the civilization that two great strains of faith had built, and that was now sliding toward ruin? But Ervin could not have been the protagonist of Szerb's novel. It is rather his Everyman Mihály, whom everyone instructs and no one finally persuades, who plays this role. As Éva finally tells him, in this deathhaunted novel, "Everyone has to find his own death". Europe, too, would soon find a moral death of its own.

Peter Hargitai, a distinguished translator and author in his own right, has given three decades of his life to Szerb and his novel, and the present translation is a revision of the one originally published in 1994. It is a labor of love that well rewards the reader, supple and idiomatic and faithful at all times to the turns - and the high eloquence too - of Szerb's masterful voice.

Antal Szerb. Traveler and the Moonlight. Translated by Peter Hargitai. Seventieth Anniversary Edition. Bloomington, Indiana: iUniverse. 272 pages. US\$17.95. 